\title{
The Influence of Age and Winter Environment on Protein Block Intake Behavior of Beef Cattle Winter Grazing Mixed-Grass Rangelands ${ }^{\dagger}$
}

\author{
Samuel A. Wyffels ${ }^{1, *}{ }^{\mathbb{D}}$, Cory T. Parsons ${ }^{1}$, Julia M. Dafoe ${ }^{1}$, Darrin L. Boss ${ }^{1}$, Boone H. Carter ${ }^{2}$ \\ and Timothy DelCurto ${ }^{3}$ (D)
}

1 Northern Agricultural Research Center, Montana State University, Havre, MT 59501, USA; Cory.Parsons2@chsinc.com (C.T.P.); jdafoe@montana.edu (J.M.D.); dboss@montana.edu (D.L.B.)

2 PerforMix Nutrition Systems, Nampa, ID 83687, USA; Boone.Carter@PerformixNutrition.com

3 Department of Animal and Range Sciences, Montana State University, Bozeman, MT 59717, USA; timothy.delcurto@montana.edu

* Correspondence: samwyffels@montana.edu

$+\quad$ This paper is an extended version of the conference proceeding: Wyffels, S.A., Parsons, C.T., Dafoe, J.M., Boss, D.L., McClain, T.P., Carter, B.H., DelCurto, T. 2020. The influence of age and winter environment on Rumax Bovibox and Bovibox HM supplement intake behavior of winter grazing beef cattle on mixed-grass rangelands. In Western Section American Society of Animal Science, Madison, WI, USA, 19-23 July 2020; Translational Animal Science, pp. S37-S42.

Citation: Wyffels, S.A.; Parsons, C.T.; Dafoe, J.M.; Boss, D.L.; Carter, B.H.;

DelCurto, T. The Influence of Age and Winter Environment on Protein Block Intake Behavior of Beef Cattle Winter Grazing Mixed-Grass Rangelands. Ruminants 2021, 1, 191-201. https:// doi.org/10.3390/ruminants1020014

Academic Editor: Brian J. Leury

Received: 29 July 2021

Accepted: 7 December 2021

Published: 9 December 2021

Publisher's Note: MDPI stays neutral with regard to jurisdictional claims in published maps and institutional affiliations.

Copyright: $\odot 2021$ by the authors. Licensee MDPI, Basel, Switzerland. This article is an open access article distributed under the terms and conditions of the Creative Commons Attribution (CC BY) license (https:// creativecommons.org/licenses/by/ $4.0 /)$.
Abstract: This study evaluated the influence of cow age and temperature adjusted for windchill ( $\mathrm{T}_{\text {windchill }}$ ) on supplement intake behavior of cattle winter grazing rangelands. A mixed-age herd of Angus-based cows (291 and 316 in year 1 and 2, respectively) were classified by age (1-, 2-, 3-, 4-, 5-7-, and $\geq 8$-year-old) and grazed rangeland pasture (329-ha) for two consecutive winters. Cows were provided free-choice access to supplement protein blocks in a SmartFeedPro self-feeder system. An Onset HOBO Weather Station collected data throughout the grazing period. Supplement intake (expressed as $\mathrm{kg} \cdot \mathrm{d}^{-1}$ and $\mathrm{g} \cdot \mathrm{kg}$ body weight ${ }^{-1}$ ), the coefficient of variation in supplement intake and intake rate $\left(\mathrm{g} \cdot \mathrm{min}^{-1}\right)$ displayed $\mathrm{T}_{\text {windchill }} \times$ cow age $\times$ year interactions $(p \leq 0.02)$. In general, cow age displayed a quadratic effect on all supplement intake variables $(p \leq 0.04)$, where 3- to 4-year-old cattle had the greatest supplement intake with the least variation, while yearling cattle had the least amount of supplement intake and the greatest variation. In conclusion, winter environmental conditions interacted with cow age to affect cattle supplement intake behavior and, consequently, the efficacy of nutrient delivery systems for beef cattle winter grazing on rangelands.

Keywords: beef cattle; cow age; environment; protein blocks; supplement intake

\section{Introduction}

During winter months, beef cattle grazing at northern latitudes are frequently exposed to chronic cold and often windy environments resulting in prolonged periods below their Lower Critical Temperature (LCT). To maintain homeothermy during conditions below the LCT, cattle raise their resting metabolic rate resulting in an increase in energy expenditure [1-3]. In response to the increased thermoregulatory demands in severe cold conditions, cattle typically increase intake [4-6]. However, forages under winter grazing conditions at northern latitudes are often dormant, resulting in a low-quality, high fiber forage resource. Voluntary intake is limited by forage fiber content NDF [7-9], suggesting cattle may not be able to increase intake to the level required to meet the increased metabolic demands to maintain homeothermy.

Supplemental crude protein (CP) is often provided to winter grazing cattle to meet nutritional needs, increase digestibility and intake of low-quality forages, and, subsequently, maintain a desired level of productivity [10-12]. Under many rangeland cattle production 
scenarios, self-fed protein blocks are often used to supplement grazing cattle due to the ease of delivery and reduction in labor. Self-fed supplementation programs presume all cattle meet a target supplement intake daily; however, overconsumption results in increased costs, and underconsumption results in animals not meeting their nutrient requirements [13]. Many protein blocks are designed to limit overconsumption with a combination of physical attributes (hardness) and added salt while decreasing underconsumption with the addition of molasses [13-15]. Nevertheless, in a mixed-age cow herd, the age of individual cattle can be a significant factor affecting supplement intake and behavior [16-18]. Although cow age has been demonstrated to influence supplement intake, data are limited relative to the variation of protein block intake in mixed-aged cattle herds winter grazing rangelands at northern latitudes. The paucity of data related to individual animal supplement intake and intake behavior is primarily due to the difficulty of measuring the intake behavior of cattle offered self-fed supplements while grazing in extensive environments [19]. Thus, research that refines supplementation strategies is needed to enhance nutrient delivery to cattle grazing in extensive rangeland environments.

Short-term behavioral responses due to extreme weather conditions may play an essential role in the energy balance of grazing beef cattle [20]. Thus, supplement intake behavior of grazing beef cattle during winter months is likely altered due to extreme weather conditions that increase the energy needed to maintain homeothermy. Consequently, the objectives of this study were to evaluate the effects of winter environmental conditions and cow age on supplement intake behavior of cattle provided a self-fed protein block while grazing winter rangelands.

\section{Materials and Methods}

The use of animals in this study was approved by the Agricultural Animal Care and Use Committee of Montana State University (\#2018-AA12). The Montana Agricultural Experiment Stations provided all animals.

For two consecutive years, cattle from a commercial mixed-age (1- to 12-year-old), non-lactating, pregnant, Angus and Simmental $\times$ Angus herd (291 cows year 1, 316 cows year 2) were allotted to one of six age classifications (1-, 2-, 3-, 4-, 5-7-, and $\geq 8$-year-olds; $\mathrm{N}=59,64,41,30,46,51$ in year 1 and 74, 49,56, 37, 47, 53 in year 2, respectively) and grazed on winter rangeland pasture for 45-days starting in mid-November and ending in early January (329-ha; 1.5 Animal Unit Month $\cdot \mathrm{ha}^{-1}$ ). Two hundred forty-two cows from year 1 were also present in year 2. Cattle had no access to roofed shelter or windbreaks during the winter grazing period. Individual cow body weight, hair thickness, and body condition scores (BCS; 1-9 scale) were obtained following a $16 \mathrm{~h}$ shrink at the initiation of the grazing trial (average body weight $=562.93 \mathrm{~kg}$; average hair thickness $=5 \mathrm{~cm}$ winter coat; average $\mathrm{BCS}=5.5$ ). During the entirety of the winter grazing period, all cattle had free-choice access to a canola meal-based protein block supplement $(28.7 \%$ CP year 1 and $30 \%$ CP year 2 ; Table 1), provided ad libitum in a SmartFeed Pro self-feeder system (C-Lock Inc., Rapid City, SD, USA) with a total of 8 feeding stations. The target daily intake range was 0.45 to $0.91 \mathrm{~kg} \cdot \mathrm{d}^{-1}$ based on manufacturers' recommendations for meeting essential supplemental protein, mineral, and vitamin requirements for grazing beef cattle. Physical consistency, $23 \%$ salt, and bitterness were used to limit daily intake. Individual animals were equipped with an electronic identification tag attached to the left ear (Allflex USA, Inc., Dallas-Ft. Worth, TX, USA). A SmartFeed Pro system equipped with electronic identification tag readers was then used for measuring individual daily supplement intake, expressed as $\mathrm{kg} \cdot \mathrm{d}^{-1}$ and $\mathrm{g} \cdot \mathrm{kg}$ body weight ${ }^{-1} \cdot \mathrm{d}^{-1}$, intake rate $\left(\mathrm{g} \cdot \mathrm{min}^{-1}\right)$, and the total time individual cows spent at the feeder $\left(\mathrm{min} \cdot \mathrm{d}^{-1}\right)$. The variation of supplement intake expressed as the coefficient of variation $(\mathrm{CV}, \%)$ was calculated based on daily intake measurement for individual cattle. All cattle had previous exposure to automated feeders in previous years. Cattle were allotted a 21-day adaption to protein block and supplement feeders each year prior to recording supplement intake behavior. 
Table 1. Composition of supplement provided to cattle winter grazing rangeland pasture for 2 consecutive years at the Northern Agricultural Research Center Thackeray Ranch, Havre, MT, USA (as-fed basis) ${ }^{1}$.

\begin{tabular}{|c|c|c|}
\hline & Year $1^{2}$ & Year $2^{3}$ \\
\hline Crude Protein & $28.7 \% \min$ & $30 \% \min$ \\
\hline Crude Fat & $1.45 \% \min$ & $1.5 \% \min$ \\
\hline Crude Fiber & $5.0 \% \max$ & $5.0 \% \max$ \\
\hline \multirow[b]{2}{*}{ Calcium } & $1.3 \% \mathrm{~min}$ & $1.3 \% \mathrm{~min}$ \\
\hline & $1.8 \% \max$ & $1.8 \% \max$ \\
\hline Phosphorus & $0.7 \% \min$ & $0.7 \% \min$ \\
\hline \multirow[b]{2}{*}{ Salt } & $23 \% \min$ & $23 \% \min$ \\
\hline & $26 \% \max$ & $26 \% \max$ \\
\hline Potassium & $1.5 \% \min$ & $1.5 \% \min$ \\
\hline Magnesium & $2.5 \% \min$ & $1.0 \% \min$ \\
\hline Manganese & 856 ppm min & 880 ppm min \\
\hline Zinc & 1074 ppm min & 1100 ppm min \\
\hline Copper & 213 ppm min & $220 \mathrm{ppm} \min$ \\
\hline Copper (from Chelate) & 108 ppm min & $110 \mathrm{ppm}$ min \\
\hline Cobalt & 15 ppm min & 16 ppm min \\
\hline Iodine & $26 \mathrm{ppm} \min$ & $25 \mathrm{ppm} \min$ \\
\hline \multirow[b]{2}{*}{ Selenium } & $3.3 \mathrm{ppm}$ min & $3.3 \mathrm{ppm}$ min \\
\hline & $3.6 \mathrm{ppm} \max$ & $3.6 \mathrm{ppm} \max$ \\
\hline Selenium Yeast & $\underline{\mathrm{PT}}$ & $1.7 \mathrm{ppm}$ \\
\hline Vitamin A & $12,000 \mathrm{IU} / \mathrm{lb}$ & $40,800 \mathrm{IU} / \mathrm{lb}$ \\
\hline Vitamin D & $4000 \mathrm{IU} / \mathrm{lb}$ & $4500 \mathrm{IU} / \mathrm{lb}$ \\
\hline Vitamin E & $25 \mathrm{IU} / \mathrm{lb}$ & $50 \mathrm{IU} / \mathrm{lb}$ \\
\hline NPN not more than & $9.7 \%$ & $9.9 \%$ \\
\hline
\end{tabular}

${ }^{1}$ Data adapted from Wyffels et al., 2020 [21]; ${ }^{2}$ Rumax BoviBoxHM (PerforMix Nutrition Systems, Nampa, ID, USA); ${ }^{3}$ Rumax BoviBox (PerforMix Nutrition Systems, Nampa, ID, USA). Supplement ingredients: Canola Meal, Salt, Dehulled Soybean Meal, Concentrated Separator By-Products, Cane Molasses, Magnesium Oxide, Urea, Calcium Carbonate, Phosphoric Acid, Magnesium Chloride, Vegetable Oil, Zinc Sulfate, Manganese Sulfate, Copper Amino Acid Complex, Selenium Yeast, Copper Sulfate, Vitamin E Supplement Zinc Amino Acid Complex, Manganese Amino Acid Complex, Copper Amino Acid Complex, Cobalt Glucoheptonate, Cobalt Sulfate, Ethylenediamine Dihydroiodide, Sodium Selenite, Vitamin A Supplement, Vitamin D3 Supplement.

As described by Wyffels and coworkers [18], the National Weather Service formula adapted for cattle [22-24] was used to calculate daily average temperatures adjusted for windchill $\left(\mathrm{T}_{\text {windchill }}\right)$. An Onset weather station (HOBO U30-NRC; Bourne, MA, USA) automated to accumulate and store ambient air temperature and wind speed data at 15 min intervals for the entire 45-day grazing period was placed near the SmartFeed Pro system. Daily average temperatures adjusted for windchill were then combined with daily supplement intake measurements for each cow for the entire winter grazing period (Table S1). Within each year of the winter grazing study, daily $\mathrm{T}_{\text {windchill }}$ conditions were categorized as below-average ( $<-1 \mathrm{SD}$ below the mean), average ( $\pm 1 \mathrm{SD}$ from mean), or above-average ( $>+1 \mathrm{SD}$ above the mean; Table 2$)$.

This research was performed at Montana State University Northern Agriculture Research Center Thackeray Ranch $\left(48^{\circ} 21^{\prime} \mathrm{N} 109^{\circ} 30^{\prime} \mathrm{W}\right)$. The Thackeray Ranch is located 21-km south of Havre, MT, USA, and is characterized as a semi-arid steppe (average annual precipitation $410 \mathrm{~mm}$ ). Kentucky bluegrass (Poa pratensis L.), rough fescue (Festuca scabrella Torr.), and bluebunch wheatgrass (Pseudoregnaria spicata [Pursh] A. Love) account for the majority of available forage. To estimate forage biomass and quality prior to the winter grazing period each year, 10 randomly placed $0.25 \mathrm{~m}^{2}$ plots clipped at a $2 \mathrm{~cm}$ height and put in a forced-air oven set at $55^{\circ} \mathrm{C}$ for $72 \mathrm{~h}$. Forage samples were then weighed to estimate dry matter biomass $\left(\mathrm{kg} \cdot \mathrm{ha}^{-1}\right.$; Table 3$)$. Forage samples were then composited by year, ground in a Wiley mill (1-mm screen), and sent to a commercial forage lab (Dairy One, Ithaca, NY, USA) for CP, NDF, ADF, and TDN analysis (Table 3). 
Table 2. Below, average, above, and overall mean temperature $\left({ }^{\circ} \mathrm{C}\right)$, wind speed $\left(\mathrm{km} \cdot \mathrm{h}^{-1}\right)$, and temperature adjusted for windchill $\left(\mathrm{T}_{\text {windchill }} ;{ }^{\circ} \mathrm{C} ; \pm \mathrm{SE}\right)$ for the 2 years of winter grazing northern mixed-grass prairie rangeland ${ }^{1}$.

\begin{tabular}{ccccc}
\hline & \multicolumn{3}{c}{ Weather Classification } & \multirow{2}{*}{ Overall Mean } \\
\cline { 2 - 4 } & Below-Average & Average & Above-Average & \\
Year 1 & & & & \\
Temperature, ${ }^{\circ} \mathrm{C}$ & $-8.10 \pm 1.13$ & $0.91 \pm 0.61$ & $8.20 \pm 0.30$ & $0.58 \pm 0.83$ \\
Wind Speed, $\mathrm{km} \cdot \mathrm{h}^{-1}$ & $5.89 \pm 0.70$ & $22.77 \pm 0.99$ & $42.56 \pm 2.10$ & $22.90 \pm 1.64$ \\
$\mathrm{~T}_{\text {windchill, }}{ }^{\circ} \mathrm{C}$ & $-18.69 \pm 1.23$ & $-7.10 \pm 0.61$ & $1.46 \pm 0.43$ & $-7.17 \pm 0.90$ \\
\hline Year 2 & & & & \\
Temperature, ${ }^{\circ} \mathrm{C}$ & $-9.87 \pm 0.54$ & $-0.86 \pm 0.57$ & $6.94 \pm 1.14$ & $-1.22 \pm 0.81$ \\
Wind Speed, $\mathrm{km} \cdot \mathrm{h}^{-1}$ & $6.08 \pm 0.71$ & $22.20 \pm 1.66$ & $42.27 \pm 1.20$ & $22.19 \pm 1.99$ \\
$\mathrm{~T}_{\text {windchill, }}{ }^{\circ} \mathrm{C}$ & $-17.89 \pm 0.74$ & $-8.31 \pm 0.53$ & $-0.15 \pm 1.33$ & $-9.12 \pm 0.84$ \\
\hline
\end{tabular}

${ }^{1}$ Data adapted from Wyffels et al., 2020 [21].

Table 3. Average forage biomass $\left(\mathrm{kg} \cdot \mathrm{ha}^{-1}\right)$, crude protein $(\mathrm{CP}, \%)$, neutral detergent fiber (NDF; \%), acid detergent fiber (ADF; \%), and total digestible nutrients (TDN; \%) on a dry matter basis of the experimental pasture for the 2 years of winter grazing northern mixed-grass prairie rangeland ${ }^{1}$.

\begin{tabular}{cccccc}
\hline & Biomass (kg·ha $^{-1}$ ) & CP (\%) & NDF (\%) & ADF (\%) & TDN (\%) \\
\hline Year 1 & 1790 & 5.4 & 63.2 & 41.9 & 56.0 \\
Year 2 & 1456 & 5.4 & 66.9 & 39.9 & 55.0 \\
\hline
\end{tabular}

${ }^{1}$ Data adapted from Wyffels et al., 2020 [21].

Individual daily supplement intake expressed as both $\mathrm{kg} \cdot \mathrm{d}^{-1}$ and $\mathrm{g} \cdot \mathrm{kg}$ body weight ${ }^{-1} \cdot \mathrm{d}^{-1}$, variation in supplement intake $(\% \mathrm{CV})$, intake rate $\left(\mathrm{g} \cdot \mathrm{min}^{-1}\right)$, and time spent at the SmarFeed Pro feeder $\left(\mathrm{min} \cdot \mathrm{d}^{-1}\right)$ were all analyzed with a generalized linear mixed model lme4 [25] in an ANOVA framework car [26] with the fixed effects of cow age, year, $T_{\text {windchill }}, T_{\text {windchill }} \times$ cow age, cow age $\times$ year, $T_{\text {windchill }} \times$ year, and $T_{\text {windchill }}$ $\times$ cow age $\times$ year, and the random intercept of individual cow to account for repeated measurements for each individual. Year was determined to be a fixed effect as protein block composition differed slightly across years. All data were plotted and evaluated for normality and homogeneity of variance and, if needed, transformed to satisfy the assumptions of ANOVA. An alpha $\leq 0.05$ was considered significant, and tendencies were considered at an alpha $\leq 0.10$. The Tukey method was used to separate means when alpha was $<0.05$. Linear and quadratic effects for each analysis were determined using orthogonal polynomial contrasts. All analyses were conducted in $\mathrm{R}$ version 4.0 .5 [27].

\section{Results}

Supplement intake expressed as $\mathrm{kg} \cdot \mathrm{d}^{-1}$ exhibited a $\mathrm{T}_{\text {windchill }} \times$ cow age $\times$ year interaction ( $p=0.02$; Figure 1). In year 1 , a tendency $(p \leq 0.10)$ was observed for 2-, 3-, and 4 -year-old cattle to have greater daily supplement intakes than yearling cattle at belowaverage $T_{\text {windchill }}$ (Figure 1A). Under average $T_{\text {windchill }}$ conditions in year 1 , there was a quadratic effect $(p<0.01)$ of cow age on supplement intake (Figure 1B), however, the quadratic effect was restricted to 3- and 4-year-old having greater $(p \leq 0.02)$ and 5-7- and $\geq 8$-year-old cattle tending $(p \leq 0.09)$ to have greater daily supplement intakes compared to yearling cattle. At above-average $\mathrm{T}_{\text {windchill }}$ in year 1 , there were no observed effects of age on daily supplement intake ( $p \geq 0.15$; Figure 1C). In the second year of the study, there was a quadratic effect $(p<0.01)$ of cow age on daily supplement intake observed for all $\mathrm{T}_{\text {windchill }}$ conditions (Figure 1D-F). During below-average $\mathrm{T}_{\text {windchill }}$ conditions, 5-7and $\geq 8$-year-old cattle had lower $(p<0.01)$ daily supplement intakes compared to 2 - and 3 -year-old cattle (Figure 1D). Additionally, 5-7-year-old cattle had lower $(p=0.04)$, and $\geq 8$-year-old cattle tended $(p=0.09)$ to have lower daily supplement intakes compared to 4 -year-old cattle. Furthermore, at below-average $\mathrm{T}_{\text {windchill }}$ conditions in year 2 , yearling 
cattle had lower $(p<0.01)$ daily supplement intake compared to 3-year-old cattle. During year 2 average $T_{\text {windchill }}$ conditions, all age groups of cattle had greater $(p<0.01)$ daily supplement intake compared to yearlings, while 5-7- and $\geq 8$-year-old cattle had lower $(p<0.01)$ daily supplement intakes compared to 3- and 4-year-old cattle. Additionally, 5 -7-year-old cattle had lower $(p=0.05)$ and $\geq 8$-year-old cattle tended $(p=0.06)$ to have lower daily supplement intakes compared to 2-year-old cattle (Figure 1E). During year 2 above-average $\mathrm{T}_{\text {windchill }}$ conditions, yearlings, $2-, 5-7-$, and $\geq 8$-year-old cattle had lower $(p \leq 0.01)$ daily supplement intakes compared to 3-year-old cattle, with yearlings tending $(p \leq 0.06)$ to have lower daily supplement intake compared to 4 - and $\geq 8$-year-old cattle (Figure 1F).

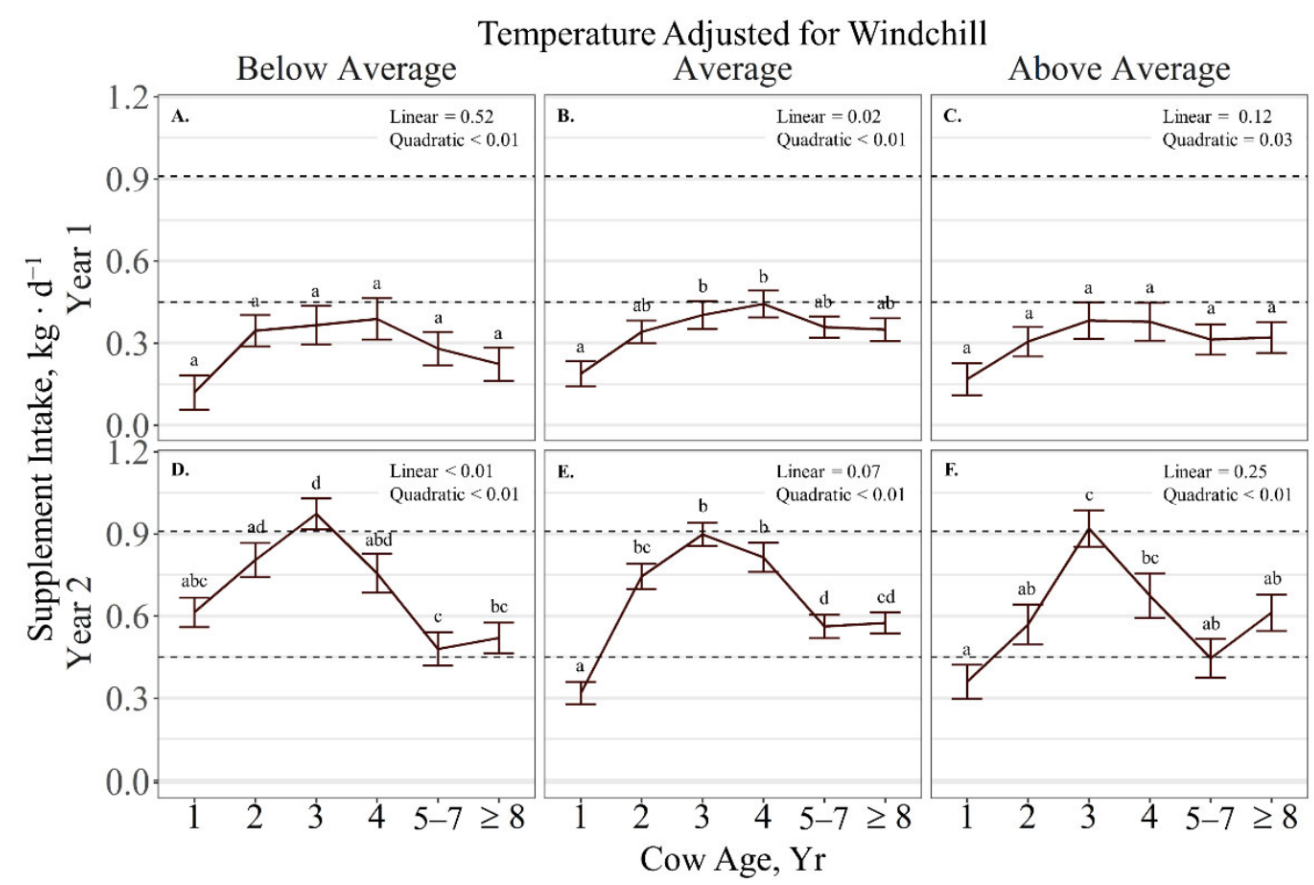

Figure 1. The effect of cow age $\times$ year $\times$ temperature classification (adjusted for windchill; $p=0.02$ ) on daily supplement intake $\left(\mathrm{kg} \cdot \mathrm{d}^{-1} \pm \mathrm{SE}\right.$; (A-F)) for 2 consecutive years by cattle winter grazing northern mixed-grass rangeland. Dashed lines indicate the target intake range. Data points without a common letter differ $(p<0.05)$. Data adapted from Wyffels et al., 2020 [21].

The coefficient of variation of supplement intake (\%) exhibited a $\mathrm{T}_{\text {windchill }} \times$ cow age $\times$ year interaction $(p=0.01$; Figure 2). In both years of the study, cow age displayed a quadratic effect $(p \leq 0.04)$ on the variation of supplement intake for all $\mathrm{T}_{\text {windchill }}$ conditions. However, in year 1, the effect of cow age was restricted to all age classes of cattle having lower $(p \leq 0.02)$ variation in supplement intake compared to yearling cattle under all $\mathrm{T}_{\text {windchill }}$ conditions (Figure 2A-C), with 5-7-year-old cattle having lower $(p=0.01)$ and 4 -year-old cattle tending $(p=0.09)$ to have lower variation in supplement intake compared to 2-year-old cattle during average $\mathrm{T}_{\text {windchill }}$ conditions (Figure 2B). During year 2 belowaverage $\mathrm{T}_{\text {windchill }}$ conditions, $5-7$ - and $\geq 8$-year-old cattle had greater $(p<0.01)$ variation in supplement intake compared to 3-year-old cattle (Figure 2D). Additionally, 5-7-year-old cattle tended $(p \leq 0.07)$ to have greater supplement intake variation than yearling and 4-year-old cattle. During year 2 average $T_{\text {windchill }}$ conditions, all age categories of cattle had lower $(p<0.01)$ variation in supplement intake compared to yearling cattle, with 2 and $\geq 8$-year-old having greater $(p \leq 0.01)$ and 5-7-year-old cattle tending $(p=0.09)$ to have greater variation in supplement intake compared to 3-year-old cattle (Figure 2E). During year 2 above-average $T_{\text {windchill }}$ conditions, yearling cattle had greater $(p<0.01)$ variation in supplement intake compared to 3-year-old cattle, with a tendency $(p=0.09)$ to have greater variation in supplement intake compared to $\geq 8$-year-old cattle (Figure 2F). 


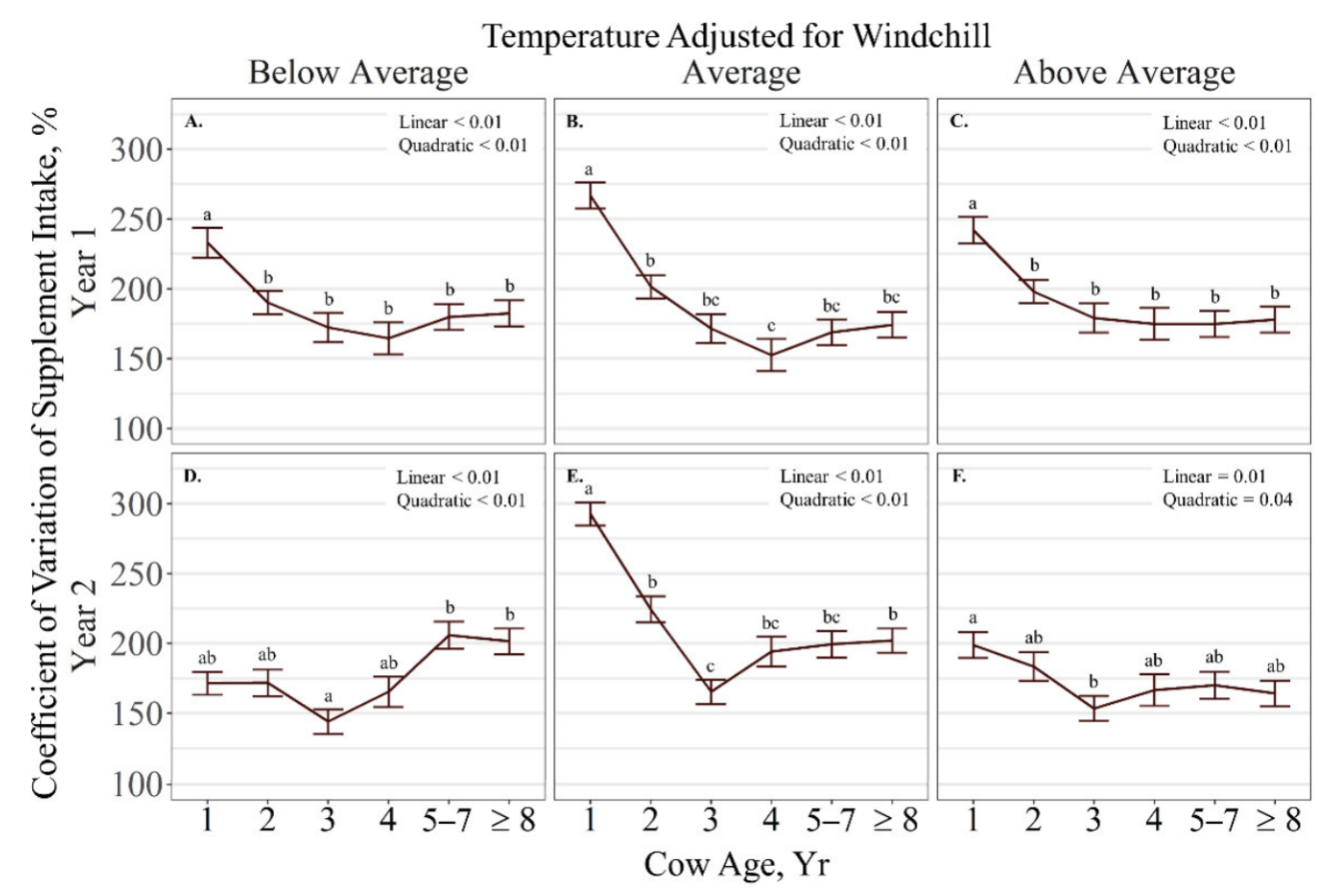

Figure 2. The effect of cow age $\times$ year $\times$ temperature classification (adjusted for windchill; $p=0.01$ ) on the coefficient of variation of supplement intake ( $\% \pm \mathrm{SE}$; (A-F)) for 2 consecutive years by cattle winter grazing northern mixed-grass rangeland. Data points without a common letter differ $(p<0.05)$. Data adapted from Wyffels et al., 2020 [21].

Supplement intake expressed as $\mathrm{g} \cdot \mathrm{kg}$ body weight ${ }^{-1} \cdot \mathrm{d}^{-1}$ exhibited a $\mathrm{T}_{\text {windchill }} \times$ cow age $\times$ year interaction $(p<0.01$; Figure 3$)$. In year 1 , there was a tendency $(p \leq 0.10)$ for yearling cattle to have lower supplement intakes per kg body weight compared to 2-yearold cattle at below-average $T_{\text {windchill }}$ conditions and 4-year-old cattle at average $T_{\text {windchill }}$ (Figure $3 \mathrm{~A}, \mathrm{~B}$ ), with no age effects on supplement intake observed at above-average $\mathrm{T}_{\text {windchill }}$ $(p \geq 0.39$; Figure 3C). In the second year of the study, there was a quadratic effect $(p<0.01)$ of cow age on supplement intake per kg body weight observed for all $\mathrm{T}_{\text {windchill }}$ conditions (Figure 3D-F). During year 2 below-average $T_{\text {windchill }}$ conditions, 5-7- and $\geq 8$-year-old cattle had lower $(p \leq 0.05)$ daily supplement intakes per $\mathrm{kg}$ body weight compared to yearling, 2- and 3-year-old cattle (Figure 3D). Additionally, yearling and 4-year-old cattle had lower $(p \leq 0.05)$ supplement intakes per kg body weight compared to 3-year-old cattle, with 5-7-year-old cattle having lower $(p=0.03)$ supplement intakes per $\mathrm{kg}$ body weight compared to 4-year-old cattle. During year 2 average $T_{\text {windchill }}$ conditions, 2-, 3-, and 4 -year-old cattle had greater supplement intake per $\mathrm{kg}$ body weight compared to yearlings, 5-7- and $\geq 8$-year-old cattle $\left(p<0.01\right.$; Figure 3E). Above-average $\mathrm{T}_{\text {windchill }}$ in year 2 resulted in 3-year-old cattle having greater supplement intake per kg body weight than all other age classifications $(p \leq 0.05$; Figure $3 \mathrm{~F})$.

Supplement intake rate $\left(\mathrm{g} \cdot \mathrm{min}^{-1}\right)$ also displayed a $\mathrm{T}_{\text {windchill }} \times$ cow age $\times$ year interaction $(p<0.01$; Figure 4$)$. During the first year of the study, there were no observed effects $(p \geq 0.17)$ of cow age on supplement intake rate regardless of $\mathrm{T}_{\text {windchill }}$ conditions (Figure $4 \mathrm{~A}-\mathrm{C})$. In the second year of the study, there was a quadratic effect $(p \leq 0.02)$ of cow age on supplement intake rate observed for all $\mathrm{T}_{\text {windchill }}$ conditions (Figure $4 \mathrm{D}-\mathrm{F}$ ). During year 2 below-average $T_{\text {windchill }}$ conditions, yearlings, 2-, 5-7- and $\geq 8$-year-old cattle had lower $(p \leq 0.02)$ intake rates compared to 3-year-old cattle (Figure 4D). Additionally, 4 -year-old cattle had a greater intake rate compared to $\geq 8$-year-old cattle $(p=0.04)$ and tended $(p=0.07)$ to be greater than 5-7-year-old cattle. During year 2 average $\mathrm{T}_{\text {windchill }}$ conditions, all cattle age groups had greater $(p \leq 0.02)$ intake rates than yearling cattle (Figure 4E), while 3-, 4- and 5-7-year-old cattle had a greater $(p<0.01)$ rate of intake than 2-year-old cattle. In addition, 3- and 5-7-year-old cattle had a greater intake rate than 
$\geq 8$-year-old cattle $(p \leq 0.02)$. During year 2 , above-average $\mathrm{T}_{\text {windchill }}$ conditions, yearling and 2-year-old cattle had a lower $(p \leq 0.01)$ intake rate compared to 3-year-old cattle, with no differences observed for other age classifications of cattle ( $p \geq 0.18$; Figure $4 \mathrm{~F})$.

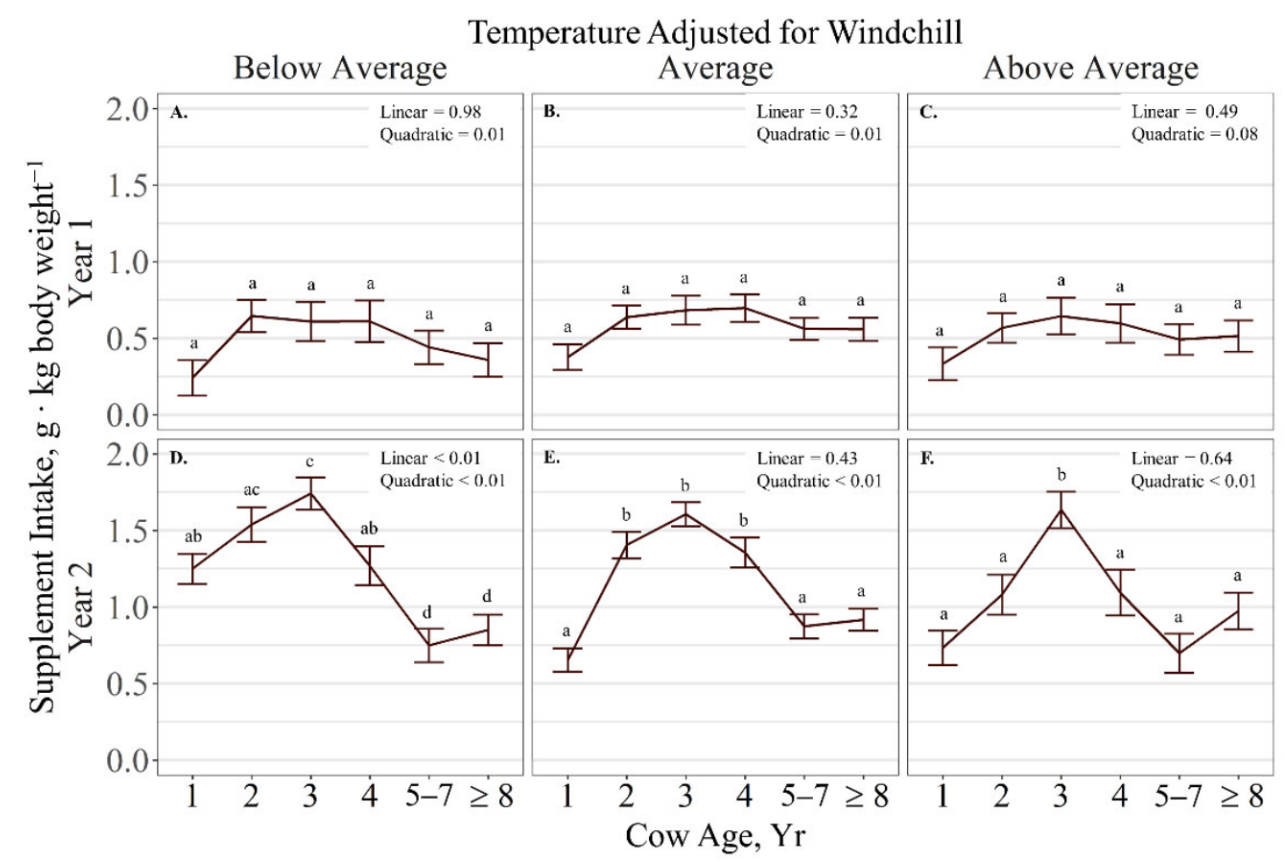

Figure 3. The effect of cow age $\times$ year $\times$ temperature classification (adjusted for windchill; $p<0.01$ ) on average daily supplement intake ( $\mathrm{g} \cdot \mathrm{kg}$ body weight ${ }^{-1} \pm \mathrm{SE}$; (A-F)) for 2 consecutive years by cattle winter grazing northern mixed-grass rangeland. Data points without a common letter differ $(p<0.05)$.

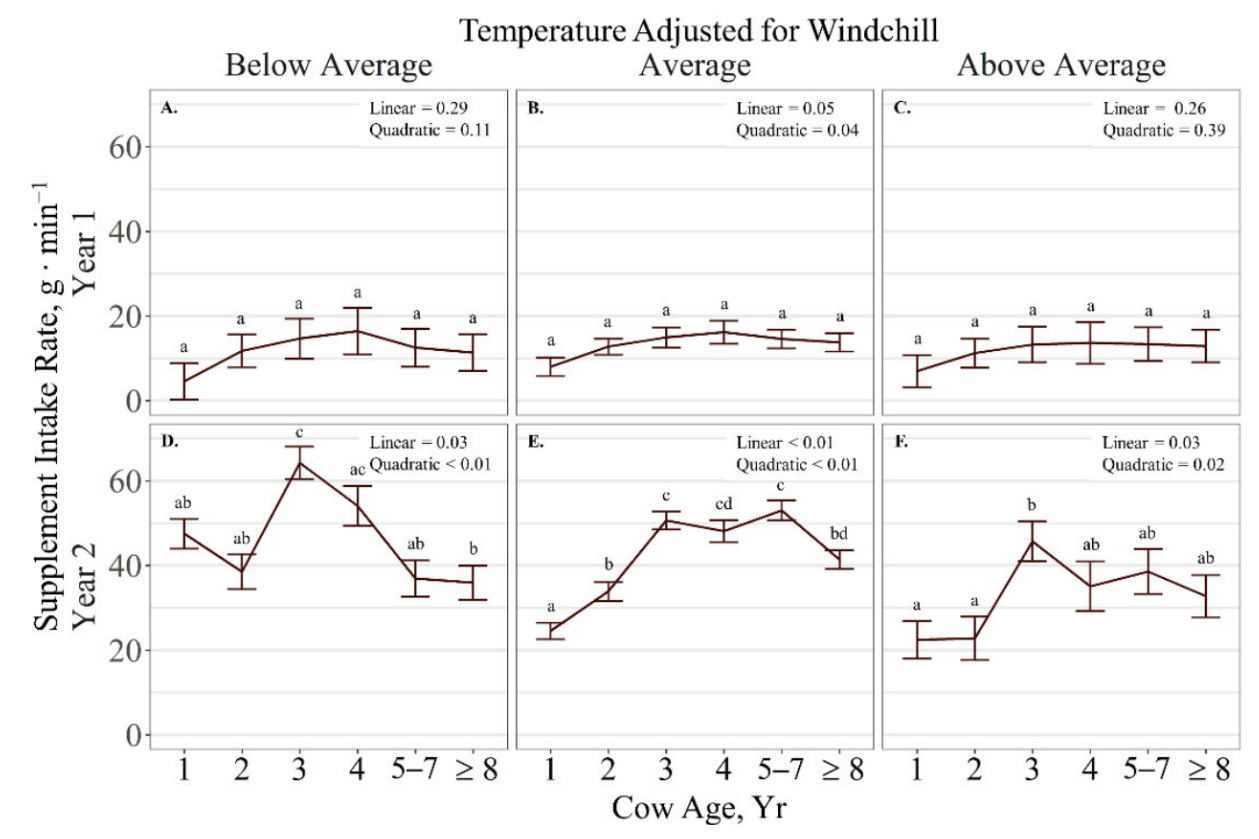

Figure 4. The effect of cow age $\times$ year $\times$ temperature classification (adjusted for windchill; $p<0.01$ ) on supplement intake rate $\left(\mathrm{g} \cdot \mathrm{min}^{-1} \pm \mathrm{SE}\right.$; (A-F)) for 2 consecutive years by cattle winter grazing northern mixed-grass rangeland. Data points without a common letter differ $(p<0.05)$.

Time spent at the supplement feeder $\left(\mathrm{min} \cdot \mathrm{d}^{-1}\right)$ displayed both a year $\times$ cow age interaction $\left(p<0.01\right.$; Figure 5A,B) and a year $\times \mathrm{T}_{\text {windchill }}$ interaction $(p<0.01)$. Cow age quadratically affected time spent at the supplement feeder in both years of study $(p<0.01)$. 
Though, in year 1 , the effect of cow age was restricted to all ages of cattle spending more $(p \leq 0.02)$ time at the supplement feeder compared to yearlings (Figure 5A). In the second year of the study, yearlings, $5-7$ - and $\geq 8$-year-old cattle spent less $(p<0.01)$ time at the supplement feeder compared to 3-year-old cattle. Additionally, in the second year of the study, yearlings and 5-7-year-old cattle spent less $(p \leq 0.01)$ time at the supplement feeder compared to 2-year-old cattle (Figure 5B). Furthermore, in year 1, all cattle spent a greater $(p<0.01)$ amount of time at the supplement feeder during average $\mathrm{T}_{\text {windchill }}$ conditions (12.24 $\pm 0.42 \mathrm{~min})$ compared to below and above-average conditions $(9.43 \pm 0.58$ and $10.57 \pm 0.54 \mathrm{~min}$, respectively). However, in year 2 , cattle tended $(p=0.08)$ to spend less time at the supplement feeder at above-average $\mathrm{T}_{\text {windchill }}$ conditions compared to belowaverage conditions (9.82 \pm 0.51 and $10.42 \pm 0.52 \mathrm{~min}$, respectively).

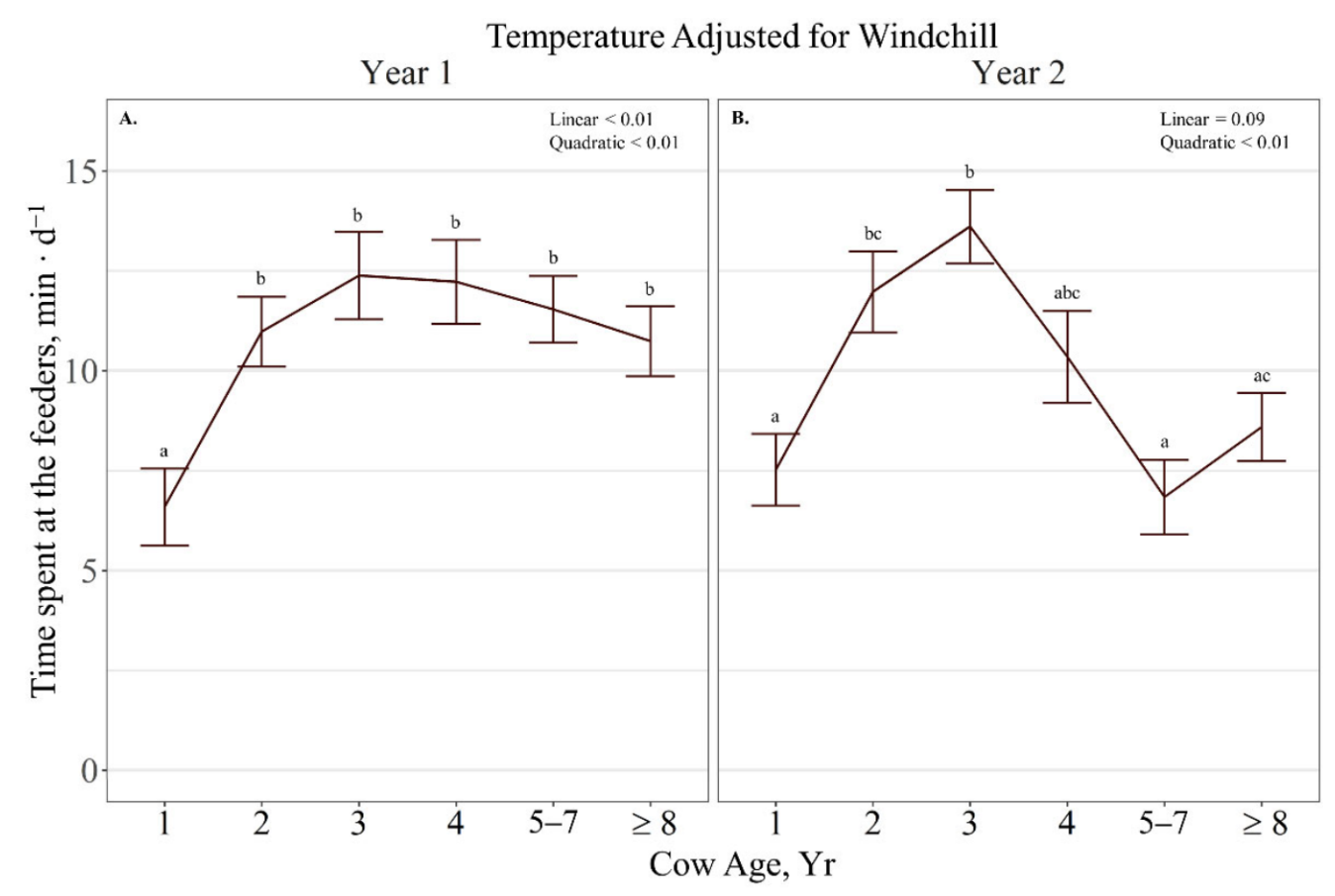

Figure 5. The effect of cow age $\times$ year $(p<0.01)$ on average time spent at the supplement feeder (min $\cdot \mathrm{d}^{-1} \pm \mathrm{SE}$; $(\mathbf{A}, \mathbf{B})$ ) by cattle winter grazing northern mixed-grass rangeland for the 2 years at the Northern Agricultural Research Center Thackeray Ranch, Havre, MT, USA. Data points without a common letter differ $(p<0.05)$. Data adapted from Wyffels et al., 2020 [21].

\section{Discussion}

The findings of this study indicate that winter weather conditions, cow age, and year interact, influencing supplement intake behavior of grazing beef cattle. However, it is probable that the effect of year on all supplement intake variables is due to differences in supplement formulation, as both weather and forage conditions were comparable across years. Both supplements used in this study were formulated similarly; however, the protein block used in the first year of the study contained $2.5 \% \mathrm{MgO}$ while the protein block used in the second year contained $1.0 \% \mathrm{MgO}$. Increasing the $\mathrm{MgO}$ content of the protein blocks also increase the bitterness and hardness of the block, which could explain the below target supplement intake range for all age groups of cattle in year 1. Our results further support that year effect is likely related to supplement formulation, as daily supplement intake and intake rate the first year of the study were nearly $50 \%$ of that observed in the second year of the study, while time spent at the supplement feeders was comparable within age classification across years. Thus, protein blocks that contain $2.5 \% \mathrm{MgO}$ to increase bitterness and hardness could result in cattle, regardless of age, not meeting the recommended target intake while winter grazing dormant northern mixed-grass rangelands. 
Previous research that has evaluated supplement intake behavior of cattle in mixedage herds suggests that older cows have greater daily supplement intake with less variation than younger cows $[16,28,29]$. In contrast to past work, our results suggest that $3-$ to 4 year-old cattle have the greatest protein block intake and are the least variable consumers. However, it should be noted that the previous work conducted to evaluate supplement intake behavior of cattle in mixed-age herds used either liquid supplements [28,29] or hand-fed delivery [16]. Additionally, all three studies measured supplement intake using serial dosing of external marker and fecal collections (5-7 days), limiting accuracy and the potential to evaluate the response of daily supplement intake behavior to varying environmental conditions [18]. Nevertheless, our findings suggest that, in general, yearling cattle spend the least amount of time at the supplement feeders and consume the least amount of supplement with the greatest variation compared to other age cattle. This result is likely related to the naivety of yearling cattle to winter grazing and protein blocks. Even though all the cattle in this study had previously been exposed to automated feeders, yearlings had limited experience with block supplements. Livestock exposed to new feeds often exhibits cautious sampling or rejection of the feed unrelated to palatability [30]. The cautious eating pattern exhibited by feedlot cattle typically lasts less than 2 weeks [31]; however, it may last longer with novel supplements when compared to an entire diet [13]. Since protein blocks are designed to limit consumption with physical attributes hardness [13,15], the inexperience of yearling cattle to physical supplement intake limiters could explain why yearling cattle generally had lower intake rates and below target supplement intake.

In ruminant livestock, maintenance energy expenditure per unit of size decreases with age [7,32-35]. Moreover, the production of metabolic heat is related to cattle body weight $[9,36]$. Therefore, younger, lighter-weight cattle are more susceptible to cold environmental conditions than the older heavier-weight herd members. Cold temperature conditions experienced while winter grazing at northern latitudes could result in greater energy requirements for young cows to maintain body temperature. Suggesting that young cows increase daily supplement intake per unit body weight and decrease variation in intake as average daily $\mathrm{T}_{\text {windchill }}$ conditions drop. Previous work that evaluated the interaction of winter conditions and cow age on cattle supplement intake behavior, when provided a pelleted self-fed protein supplement with $25 \%$ salt added to limit intake, demonstrated that supplement intake decreased, and variation of intake increased with cow age at cold temperatures [18]. Specifically, yearlings and young cattle increase supplement intake with decreased variation in response to cold temperature. The authors suggested that young cattle may have a greater dependency on the supplement to meet nutrient requirements compared to older cattle due to the poor quality of available forage while winter grazing dormant forage. Although the results of our study were quadratic, during year 2 belowaverage temperature conditions, yearling cattle increased daily supplement intake with a decreased variation. However, it should be noted that the daily supplement intake of yearling cattle was only within the manufacturers' target range at below-average temperature conditions in the second year of the study. Therefore, yearling cattle in our study were likely not meeting their nutrient requirements throughout the winter grazing period.

\section{Conclusions}

Beef cattle production and management on winter rangelands are enhanced by evaluating nutrient delivery of self-fed supplements and the interaction of cow age and environmental stress. We found that winter environmental conditions and cow age can influence supplement intake per day, variation in supplement intake, intake rate, and time spent at the supplement feeders for beef cattle provided a free-choice protein block supplement while grazing rangelands. Additionally, we found yearling cattle to have a considerable amount of variation in daily supplement intake, suggesting that supplementing a mixedaged cow herd with a self-fed protein block may not supply sufficient nutrients for yearling cattle. However, for a diverse group of cattle that are 2-year-old and older, free-choice 
canola meal-based protein blocks can be effective when provided in an extensive winter rangeland environment.

Supplementary Materials: The following are available online at https:/ /www.mdpi.com/article/ 10.3390/ruminants1020014/s1, Table S1: Animal supplement intake behavior and weather data.

Author Contributions: Conceptualization, S.A.W., T.D., D.L.B. and B.H.C.; methodology, S.A.W., T.D. and D.L.B.; formal analysis, S.A.W.; investigation, S.A.W., C.T.P., D.L.B., T.D. and J.M.D.; resources, D.L.B., T.D. and B.H.C.; data curation, S.A.W., J.M.D., C.T.P. and T.D.; writing-original draft preparation, S.A.W.; writing-review and editing, S.A.W., D.L.B., T.D., C.T.P. and J.M.D.; visualization, S.A.W.; supervision, S.A.W., D.L.B. and T.D.; project administration, C.T.P. and J.M.D.; funding acquisition, D.L.B., T.D. and B.H.C. All authors have read and agreed to the published version of the manuscript.

Funding: This research was funded by to PerforMix Nutrition Systems, the Nancy Cameron Endowment, the Bair Ranch Foundation, and the Montana Stock Growers Association.

Institutional Review Board Statement: The use of animals in this study was approved by the Agricultural Animal Care and Use Committee of Montana State University (\#2018-AA12).

Informed Consent Statement: Not applicable.

Data Availability Statement: The data presented in this study are available in Table S1.

Acknowledgments: Appreciation is expressed to PerforMix Nutrition Systems, the Nancy Cameron Endowment, the Bair Ranch Foundation, and the Montana Stock Growers Association for research funding and the employees of MSU Northern Agricultural Research Center for their assistance with this project.

Conflicts of Interest: Boone H. Carter is an employee of PerforMix Nutrition Systems, which donated the protein block supplement used in this research. However, we declare no conflict of interest regarding the writing of this manuscript.

\section{References}

1. Webster, A.J. Prediction of heat losses from cattle exposed to cold outdoor environments. J. Appl. Physiol. 1971, 30, 684-690. [CrossRef] [PubMed]

2. Christopherson, R.; Hudson, R.; Christophersen, M. Seasonal energy expenditures and thermoregulatory responses of bison and cattle. Can. J. Anim. Sci. 1979, 59, 611-617. [CrossRef]

3. Keren, E.N.; Olson, B.E. Thermal balance of cattle grazing winter range: Model application. J. Anim. Sci. 2006, 84, 1238-1247. [CrossRef] [PubMed]

4. Ames, D.R.; Ray, D.E. Environmental manipulation to improve animal productivity. J. Anim. Sci. 1983, 57, 209-220. [CrossRef]

5. Baile, C.A.; Forbes, J.M. Control of feed intake and regulation of energy balance in ruminants. Physiol. Rev. 1974, 54, 160-214. [CrossRef]

6. Arnold, G. Regulation of forage intake. In Bioenergetics of Wild Herbivores; CRC Press: Boca Raton, FL, USA, 1985; Volume 82, p. 98.

7. National Academies of Sciences, Engineering, and Medicine. Nutrient Requirements of Beef Cattle, 8th ed.; The National Academies Press: Washington, DC, USA, 2016.

8. Mertens, D.R. Regulation of forage intake. In Forage Quality, Evaluation, and Utilization; Fahey, G.C., Jr., Collins, M., Mertens, D.R., Moser, L.E., Eds.; American Society of Agronomy, Crop Science Society of America, and Soil Science Society of America: Madison, WI, USA, 1994; pp. 450-493.

9. Van Soest, P.J. Nutritional Ecology of the Ruminant, 2nd ed.; Cornell University Press: Ithaca, NY, USA, 1994.

10. Lusby, K.; Stephens, D.; Knori, L.; Totusek, R. Forage intake of range cows as affected by breed and level of winter supplement. Anim. Sci. Res. 1967, MP-96, 27-32.

11. Bodine, T.; Purvis, H.; Lalman, D. Effects of supplement type on animal performance, forage intake, digestion, and ruminal measurements of growing beef cattle. J. Anim. Sci. 2001, 79, 1041-1051. [CrossRef]

12. Bowman, J.; Sowell, B.; Paterson, J. Liquid supplementation for ruminants fed low-quality forage diets: A review. Anim. Feed Sci. Technol. 1995, 55, 105-138. [CrossRef]

13. Bowman, J.; Sowell, B. Delivery method and supplement consumption by grazing ruminants: A review. J. Anim. Sci. 1997, 75, 543-550. [CrossRef]

14. Weir, W.; Torell, D. Salt-cottonseed meal mixture as a supplement for breeding ewes on the range. J. Anim. Sci. 1953, 12, 353-358. [CrossRef]

15. Kunkle, W.; Johns, J.; Poore, M.; Herd, D. Designing supplementation programs for beef cattle fed forage-based diets. J. Anim. Sci. 2000, 77, 1-12. [CrossRef] 
16. Kincheloe, J.; Bowman, J.; Sowell, B.; Ansotegui, R.; Surber, L.; Robinson, B. Supplement intake variation in grazing beef cows. In Proceedings of the Western Section American Society of Animal Science, Corvallis, OR, USA, 16-18 June 2004; pp. 331-334.

17. Adams, D.; Nelsen, T.; Reynolds, W.; Knapp, B. Winter grazing activity and forage intake of range cows in the Northern Great Plains. J. Anim. Sci. 1986, 62, 1240-1246. [CrossRef]

18. Wyffels, S.A.; Dafoe, J.M.; Parsons, C.T.; Boss, D.L.; DelCurto, T.; Bowman, J.G.P. The influence of age and environmental conditions on supplement intake by beef cattle winter grazing northern mixed-grass rangelands. J. Anim. Sci. 2020, 98, skaa217. [CrossRef]

19. DelCurto, T.; Olson, K. Issues in grazing livestock nutrition. In Proceedings of the 4th Grazing Livestock Nutrition Conference, Estes Park, CO, USA, 9-10 July 2010; Hess, B.W., DelCurto, T., Bowman, J.G.P., Waterman, R.C., Eds.; Western Section American Society of Animal Science: Champaign, IL, USA, 2010; pp. 1-10.

20. Senft, R.L.; Rittenhouse, L.R. A model of thermal acclimation in cattle. J. Anim. Sci. 1985, 61, 297-306. [CrossRef]

21. Wyffels, S.A.; Parsons, C.T.; Dafoe, J.M.; Boss, D.L.; McClain, T.P.; Carter, B.H.; DelCurto, T. The in-fluence of age and winter environment on Rumax Bovibox and Bovibox HM supplement intake behavior of winter grazing beef cattle on mixed-grass rangelands. Transl. Anim. Sci. 2020, 4 (Suppl. S1), S37-S42. [CrossRef]

22. Osczevski, R.; Bluestein, M. The new wind chill equivalent temperature chart. Bull. Am. Meteorol. Soc. 2005, 86, 1453-1458. [CrossRef]

23. Tucker, C.B.; Rogers, A.R.; Verkerk, G.A.; Kendall, P.E.; Webster, J.R.; Matthews, L.R. Effects of shelter and body condition on the behaviour and physiology of dairy cattle in winter. Appl. Anim. Behav. Sci. 2007, 105, 1-13. [CrossRef]

24. Graunke, K.L.; Schuster, T.; Lidfors, L.M. Influence of weather on the behaviour of outdoor-wintered beef cattle in Scandinavia. Livest. Sci. 2011, 136, 247-255. [CrossRef]

25. Bates, D.; Maechler, M.; Bolker, B.; Walker, S. Fitting linear mixed-effects models using lme4. J. Stat. Softw. 2015, 67, 1-48. [CrossRef]

26. Fox, J.; Weisberg, S. An R Companion to Applied Regression, 2nd ed.; Sage: Thousand Oaks, CA, USA, 2011; Available online: http:/ / socserv.socsci.mcmaster.ca/jfox/Books/Companion (accessed on 15 November 2020).

27. R Core Team. R: A Language and Environment for Statistical Computing; R Foundation for Statistical Computing: Vienna, Austria, 2020; Available online: http:/ / www.R-project.org/ (accessed on 15 November 2020).

28. Sowell, B.F.; Bowman, J.G.; Grings, E.E.; MacNeil, M.D. Liquid supplement and forage intake by range beef cows. J. Anim. Sci. 2003, 81, 294-303. [CrossRef]

29. Bowman, J.G.P.; Sowell, B.F.; Boss, D.L.; Sherwood, H. Influence of liquid supplement delivery method on forage and supplement intake by grazing beef cows. Anim. Feed Sci. Technol. 1999, 78, 273-285. [CrossRef]

30. Launchbaugh, K.L. Effects of neophobia and aversions on feed intake: Why feedlot cattle sometimes refuse to eat nutritious feed. In Symposium: Intake by Feedlot Cattle; Owens, F.N., Gill, D., Lusby, K., McCollun, T., Eds.; Oklahoma Agricultural Experimental Station: Stillwater, Oklahoma, USA, 1995; Volume P-942, p. 36.

31. Hicks, R.B.; Owens, F.N.; Gill, D.R.; Oltjen, J.W.; Lake, R.P. Dry matter intake by feedlot beef steers: Influence of initial weight, time on feed and season of year received in yard. J. Anim. Sci. 1990, 68, 254. [CrossRef]

32. Blaxter, K.L. The Energy Metabolism of Ruminants; Hutchinson and Co. Ltd.: London, UK, 1962.

33. Graham, N.; Searle, T.; Griffiths, D. Basal metabolic rate in lambs and young sheep. Aust. J. Agric. Res. 1974, 25, 957-971. [CrossRef]

34. CSIRO. Feeding Standards for Australian Livestock: Ruminants; Commonwealth Scientific and Industrial Research Organization, CSIRO Publishing: Melbourne, Australia, 1990.

35. CSIRO. Nutrient Requirements of Domesticated Ruminants; Commonwealth Scientific and Industrial Research Organization, CSIRO Publishing: Collingwood, Australia, 2007.

36. Thonney, M.L.; Touchberry, R.W.; Goodrich, R.D.; Meiske, J.C. Intraspecies Relationship between Fasting Heat Production and Body Weight: A Reevaluation of W.75. J. Anim. Sci. 1976, 43, 692-704. [CrossRef] 